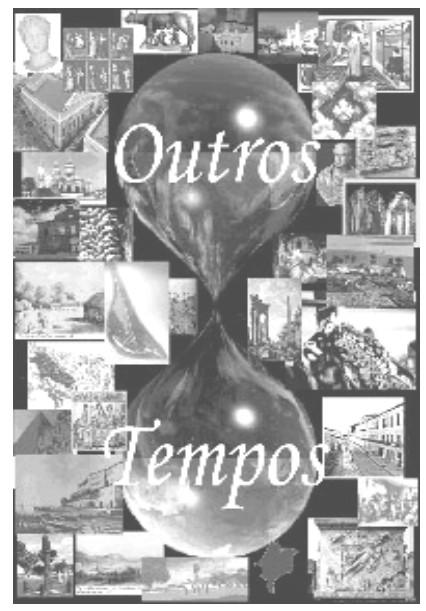

\title{
MEMÓRIAS DE NOVA IORQUE-MA: invenção imaginária de
} uma cidade.

Resumo: Este estudo toma como objeto de investigação dois momentos da vida dos moradores de Nova Iorque do Maranhão, que são as inundações e completa destruição da cidade, as ações discursivas e sociais dos moradores, no intuito de reconstruí-la física, política e simbolicamente. Para a realização desse propósito, tomaremos como material principal de análise os relatos orais dos antigos moradores, relatos esses que falam de suas experiências de vida como forma de preservação da memória individual e coletiva. Ou seja, ao construírem imagens da cidade pelas narrativas da memória, partindo de pontos de vista diferentes, lugar social que os narradores ocupam ou ocuparam nas histórias que narram, as lembranças rememoradas acabam convergindo para pontos comuns, nos permitindo pensar o universo investigado como parte de uma geração que vivenciou situações sociais próprias e que não se deixa confundir com a geração atual.

Palavras-chave: cidade, memória, oralidade.

Abstract:This study it takes as inquiry object two moments in the life of the inhabitants of New York, the discursive and social flooding and complete destruction of the city, actions of the inhabitants in intention to reconstruct it physical, politics and symbolically. For the accomplishment of this intention we will take as material by analysis the verbal stories of the old inhabitants main, stories these that speak of its experiences of life as form of preservation of the individual and collective memory. Or either, when constructing images of the city for the narratives of the memory, leaving of different social place, points of view that the narrators occupy or had occupied in histories that they tell, the recollected souvenirs finish converging to common points, in allowing to think the investigated universe as part of a generation that lived deeply proper social situations and that it is not left to confuse with the current generation.

Key words: city, memory, orality. 


\section{INTRODUÇÃO}

A melhor maneira de saber a história de um povo é o ouvindo contar. ${ }^{1}$

O texto que por hora lhes apresento é resultado parcial de uma investigação. Nele pretendo discorrer sobre relatos de memórias. Para tanto, adoto como prioridades pontos de vista expressos em entrevistas com pessoas que viveram experiências traumáticas e que compartilham de um espaço social comum em suas vidas: a cidade de Nova Iorque. ${ }^{2} \mathrm{O}$ que despertou meu interesse por essas experiências foram os dois episódios da inundação das cidades, narrados por pessoas que estiveram direta e indiretamente ligados a esses acontecimentos: a inundação de 1929 teve como causa a enchente natural do rio Parnaíba; a de 1970, por sua vez, foi resultado da intervenção do homem, no curso natural do rio, represando suas águas.

Nova Iorque foi escolhida como lugar das ações da memória, nesta pesquisa, por ali terem acontecido fatos que foram historicamente significativos e relevantes para a vida dos moradores no decorrer do processo de construção da hidroelétrica da Boa Esperança. Fui a Nova Iorque, ao encontro de homens e mulheres que vivem ali, para pedir-lhes que me confiassem uma nesga de suas memórias. Todavia, as pessoas que me ofertaram um naco de suas lembranças, não a fizeram sem antes quererem saber quem eu era, por que havia me interessado por suas histórias e as das cidades e o que pretendia fazer com ambas. É sabido que toda relação exige algo em troca. Com a pesquisa, não poderia ser diferente, por se tratar de uma relação de poder, portanto uma troca. Também é mais do que sabido que a dádiva só acontece quando há reciprocidade e para que isso ocorra, depende-se da disponibilidade do outro.

Pois bem, em meio às dificuldades em partilhar com os moradores as intenções e propósitos da pesquisa, a importância e necessidade em gravar entrevistas, aos poucos foram conquistando a confiança dos entrevistados. Uma vez aceito, o desafio foi o de encontrar as estratégias mais adequadas para interagir com as pessoas, possibilitando-lhes relatar os pontos de vista de suas representações/interpretações acerca da inundação da "Cidade

\footnotetext{
${ }^{1}$ Narradores de Javé, 100 minutos, cor, 2003; direção de Eliane Caffé, Bananeiras Filmes.

${ }^{2}$ Localizada no Médio Sertão do Maranhão, estando a $600 \mathrm{~km}$ de distância da capital São Luís, a cidade tem por divisa natural com o Estado do Piauí, o Rio Parnaíba. De acordo com os dados do censo populacional realizado pelo IBGE em 2007, Nova Iorque tem uma população de 4.892 habitantes.
} 


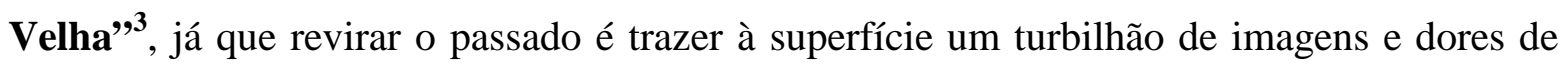
outrora. Como diz o historiador Henri Rousso: "a história da memória tem sido quase sempre uma história das feridas abertas pela memória” (ROUSSO, 2002, p. 95). Nesse sentido, lembrar da submersão da "velha cidade" é para os nova-iorquinos um exercício cotidiano da reminiscência pr'além das dores das “feridas abertas pela memória". É como arrancar com as unhas das lembranças, as bostelas de ferida. É chaga que não sara. Nos dizeres de Guimarães Rosa: "um dia é todo para esperança, o seguinte para a desconsolação" (ROSA, 2006. P. 410).

\section{DILEMAS TEÓRICO-METODOLÓGICOS: uma abordagem de campo.}

O tema desta pesquisa não são os episódios das inundações enquanto tais, mas, sim, os relatos de memórias, feitos pelos moradores da cidade de Nova Iorque. Trata-se, portanto, de um ponto de vista interpretativo da memória local. Para tanto, adoto como referência os relatos dos moradores, que por sua vez, também, são interpretações. No entanto, há que se esclarecer que não tenho a pretensão em estabelecer verdades acerca das inundações ocorridas em Nova Iorque. Tampouco, pretendo reescrever sua história. Trata-se de um esboço narrativo em analisar os meandros das memórias e representações que estão contidas nos referidos relatos. Tomo-os como pontos de partida, pilares de sustentação para construção de outra interpretação. Diz o filósofo francês Paul Ricoeur, que a interpretação “é o trabalho de pensamento que consiste em decifrar o sentido oculto do sentido aparente, em desdobrar os níveis de significação implicados na significação literal. [...] há interpretação onde houver sentido múltiplo; e é na interpretação que a pluralidade dos sentidos torna-se manifesta" (RICOEUR, 1978, p.15).

Assim sendo, visto de um ângulo apropriado, o ponto de vista interpretativo das inundações da cidade, nesta pesquisa, pauta-se em investigar, analisar e identificar, por intermédio dos relatos de memórias dos narradores, a constituição simbólica dos processos de significações, imbricados nas representações quanto à destruição/reconstrução da idade de Nova Iorque. Meu intento é analisar os significados dos rastros deixados pelas memórias, no intuito de poder desvendar as atribuições de signos que pretendem ir além da "significação literal" do que estava sendo contado pelos moradores. Diz o antropólogo francês Clifford Geertz que,

\footnotetext{
${ }^{3}$ Assim os moradores denominam a cidade submersa pelas águas da Barragem da Boa Esperança em 1969.
} 
É por intermédio dos padrões culturais, amontoados ordenados de símbolos significativos, que o homem encontra sentido nos acontecimentos através dos quais ele vive. $\mathrm{O}$ estudo da cultura, a totalidade acumulada de tais padrões, é, portanto, o estudo da maquinaria que os indivíduos ou grupos de indivíduos empregam para orientar a si mesmo num mundo que de outra forma seria obscuro (GEERTZ, 1989, p. 228).

Gigantesco amontoado de símbolos ordenados. Homens e mulheres que atribuem sentidos aos acontecimentos causados pelas inundações... Maquinaria cultural. Com propósitos em diversificar os pontos de vista, além dos relatos de memória dos moradores, também lancei mão de reportagens encontradas nos principais jornais em circulação na capital. Há que se esclarecer, no entanto, que o que se buscou encontrar nestas reportagens não foi os indícios que pudessem constatar a veracidade dos referidos relatos de memórias. De que forma os fatos foram decorridos, é o menos importante. O que importa é não perder de vista outro ângulo de possibilidade interpretativa por intermédio da imprensa. Uma visão em que se procura desvendar o que acontece por trás do dedo que aperta o gatilho e dispara símbolos de imagens veladas nas entrelinhas das reportagens, sobretudo nas que dizem respeito à construção da hidroelétrica da Boa Esperança. Multiplicidades de olhares. Profusão de enunciados. Relatos de memórias dos narradores e visão da imprensa se coadunam. Complementam-se e se confrontam. Aproximam-se e se distanciam.

Desse modo, seguindo os rastros dos relatos dos moradores, com os óculos da memória de Nova Iorque, a construção da barragem é apresentado-anunciado como o prenúncio da destruição, da desgraça, da tragédia, "uma calamidade", de acordo com os olhos de ver de Sr. Pedro:

\footnotetext{
Eles baixavam as comportas e ele (o Rio Parnaíba) vinha, parece que vinha caminhando. Aí nós juntou todo mundo para igreja, pra ir chorar lá. A água vinha pelos becos, em todos os becos da cidade que já era um lugar baixo, de várzea de carnaúba, de cocal, dessa coisa toda. Ele chega vinha assim (gesticula entremeando as mãos). Até quando fechou o cerco. Aí nós ficamos, vamos vê todo mundo no cemitério rezar pra lá e as sepulturas enchendo de água. Uns chorava pra lá e outros se maldiziam aquele negócio inteiro. Uma calamidade! (Entrevista concedida ao autor em Nova Iorque, em 20/02/2005.)
}

Tragédia anunciada, mas não conformada. Como podemos observar, ao narrar o episódio da inundação da "cidade velha", Sr. Pedro encontra, na própria experiência dos acontecimentos, os artefatos com que constrói a tessitura da sua narrativa. Semelhante aos tropos lingüísticos do "era uma vez", a narração se inicia rememorando que, ao baixarem as comportas da hidroelétrica, "ele vinha", o rio, parecia que "vinha caminhando" em direção à cidade. A imagem do rio é de uma centopéia em seu lento rastejar de mil pés. "Ele chega vinha assim", em lentos passos, foi-se apoderando das ruas da cidade. Beco por beco, "até 
quando fechou o cerco". Se o rio parecia caminhar, o desespero chega a galope. Acuados, os moradores se amontoam. Resignados, abrigaram-se na igreja. Ao pé do altar, fizeram-se aos prantos: "juntou todo mundo pra igreja, pra ir chorar lá”. A imagem que salta do relato, logo a seguir, é a do cemitério. O que se vê: "todo mundo no cemitério rezar prá lá". Pelos ossos dos seus mortos, às lágrimas somavam-se as águas do rio: "e as sepulturas enchendo..." Os prantos se alastram feito faísca de fogo em rastilho de pólvora. Das vistas desaparecem os últimos vestígios dos seus antepassados: "Uns choravam pra lá!” “Outros se maldiziam!” "Uma calamidade!".

Enquanto isso, visto de outro ângulo, com as lentes da imprensa e dos governantes, a construção da Barragem reflete as imagens do progresso. Do propalado desenvolvimento Nacional e por extensão, do Maranhão. A "Boa Esperança" nascia para redimir o Nordeste Ocidental das suas condições subumanas. Assim foi anunciada a boa nova às populações do Piauí e Maranhão nas páginas do Jornal $O$ Imparcial:

\begin{abstract}
Obra iniciada em agosto de 1964, atravessou os anos de sua realização em ritmo acelerado de trabalho, numa das regiões menos desenvolvidas do país onde inexistiam condições de infraestruturas, a usina de Boa Esperança teve característica de projeto integrado trazendo benefícios imediatos às populações do Piauí e Maranhão. Sob a coordenação da COHEBE, empresa subsidiária da ELETROBRAS, diversos órgãos federais participaram de um vasto programa que compreendeu desde a construção de novas cidades (Guadalupe no Piauí e Nova Iorque no Maranhão), até a criação do órgão (comissão de desenvolvimento dos municípios da área de Boa Esperança - DEMABE), responsável pelo desenvolvimento e instalação de unidades de saúde e assistência social e de ensino médio. ${ }^{4}$ (grifo do autor)
\end{abstract}

Prosseguindo, a reportagem reforça a esperança:

Boa Esperança nasceu, pois, do esforço de muitos. Primeiro, foi o antigo departamento nacional de portos, rios e canais (hoje DPVN), pensando em melhorar as condições de navegabilidade do Rio Parnaíba. Depois o DNOCS, seguido da SUDENE e da ELETROBRAS, que após estudos de viabilidade concluíram por um trabalho mais amplo com idéia da hidro-elétrica. Foi quando se criou a COHEBE, que nasceu para integrar a região Nordeste Ocidental no processo de desenvolvimento nacional (O IMPARCIAL,20/03/1970, p. 3).

A reportagem é longa, porém reveladora. A "Boa Esperança” é fruto do esforço de vários órgãos do Governo Federal para “integrar a região do Nordeste Ocidental no processo de desenvolvimento nacional". Juntamente com o Piauí, o Maranhão carregava nas tintas e expunha na galeria nacional os piores quadros de miséria do país. Nos horizontes do Médio Parnaíba piscavam as luzes da "Boa Esperança". Os clarões do progresso alumiavam os céus dos sertões. Os traços marcantes dos bolsões de misérias dos estados do Maranhão e Piauí - "das regiões menos desenvolvidas do país onde inexistiam condições de infra-

\footnotetext{
${ }^{4}$ Em Nova Iorque existe um posto de saúde com capacidade para 05 leitos; duas escolas: sendo uma Estadual (ensino médio) e outra municipal (ensino fundamental).
} 
estrutura" - tinham seus dias contados. Nos trilhos da "Boa Esperança", correria a locomotiva do desenvolvimentismo, do avanço industrial que vem trazer nossa "redenção". Os enunciados soavam dos apitos oficiais e oficiosos. O tom era de uma opereta industrial com seus acordes redentores da região menos desenvolvida do país, o inóspito sertão, o “Torrão do Maranhão" (LOPES, 1970, p. 67). Sob o "catecismo do fuzil”, os Generais de cinco estrelas comandam a marcha do desenvolvimentismo rumo ao Nordeste do país. O "exército da salvação" estava sob o comando do General Presidente da República: Costa e Silva. Valendo-se das páginas da imprensa escrita, assim disse mais o comandante da Nação:

Salvar o Nordeste é portanto, salvar o Brasil. Resolver o problema nordestino é da solução ao problema Nacional. [...] Nacionais, entretanto, no sentido mais profundo da expressão, devem elas serem consideradas, porque visam, no fundo e mais além do significado explícito de cada uma, à integração do país, à recomposição afetiva da federação, à solidez do sistema republicano, ao desenvolvimento do Brasil, como todo sagrado, e, enfim, à perenidade dos princípios democráticos.

E mais:

As decisões tomadas no Recife, nestes últimos dias, põem em linhas paralelas a manutenção do sistema de incentivos fiscais dos artigos 54 e 18 do plano diretor da SUDENE, a fim de que o fluxo de investimentos, que só tem verificado na região sofra solução de continuidade, mantendo-se a extensão das oportunidades de emprego, o impulsionamento da agropecuária e da pequena e média empresa, a assistência médica, a ampliação da rede rodoviária e o carreamento de recursos, para aumentar o abastecimento da água, o reaparelhamento portuário e a alfabetização, a melhoria das comunicações e o desenvolvimento do ensino técnico, a exploração de riquezas e a habitação, a irrigação, que rejuvenesce a terra, e o saneamento, que recupera perspectivas ao bem estar do homem do Piauí e Maranhão, e também o compromisso de continuar a obra encetada pelo grande Presidente Castelo Branco, fazendo prosseguir em ritmo intenso a construção da hidrelétrica de Boa esperança, que insisto em anunciar como uma "Boa Certeza" (O IMPARCIAL, 15/08/1967 p.5, Grifo meu).

Entre um ponto de vista e outro, optei por bisbilhotar pelas lentes dos relatos orais dos moradores, por vários fatores: primeiro, porque acredito que as experiências narradas por estes moradores resultam de lembranças traumáticas, de modo que os entrevistados demonstraram grandes dificuldades em relembrar a destruição da "Cidade Velha". Segundo, porque acredito ainda ser a oralidade a maneira privilegiada por este grupo de narradores que, no cotidiano, estão acostumados a dividirem entre si as experiências vividas à época da construção da barragem. Como diz Michel Pollak, é através do "trabalho de reconstrução de si mesmo que o indivíduo tende a definir seu lugar social e suas relações com os outros" (POLLAK, 1989, p.14). Assim sendo, a oralidade constitui para essas pessoas uma malha de comunicabilidade, a linha com que tecem o bordado de suas memórias. Paralelo aos relatos, o silêncio dos moradores parece uma estratégia encontrada para resistir e expressar os sentimentos de suas dores d’outrora, na medida em que "o longo silêncio sobre o passado, 
longe de conduzir ao esquecimento, é a resistência que uma sociedade civil impotente opõe ao excesso de discursos oficiais" (POLLAK, 1989, p.3).

Foi justamente por intermédio da oralidade, que busquei encontrar os pontos de vista que melhor se apropriassem e que me permitissem perceber os signos emitidos pelos relatos de memórias, e, por onde se pudessem interpretar as imagens de uma cidade submersa, na medida em que "os signos são objeto de um aprendizado temporal, não de um saber abstrato. Aprender é, de início, considerar uma matéria, um objeto, um ser, como se emitissem signos a serem decifrados, interpretados" (DELEUZE, 2006, p.4). Imagens/signos que não existem para além da memória dos narradores; Imagens/memórias de uma cidade que falece incrustada na lama da Boa Esperança; Imagens/signos/memórias que bóiam na superfície do confuso e obscuro labirinto da reminiscência, pois:

\footnotetext{
O mundo cotidiano no qual se movem os membros de qualquer comunidade, seu campo de ação social considerado garantido, é habitado não por homens quaisquer, sem rosto, sem qualidades, mas por homens personalizados e adequadamente rotulados. Os sistemas de símbolos que definem essas classes não são dados pela natureza das coisas - eles são construídos historicamente, mantidos socialmente e aplicados individualmente (GEERTZ, 1989, p.229).
}

Assim sendo, não basta que o pesquisador esteja munido do "operacionismo como dogma metodológico", e sim que seja capaz de desfazer os nós que permitam a substituição de uma "complexidade menos inteligível por outra mais inteligível” (GEERTZ, 1989, p. 45). Aos nós das memórias de Nova Iorque, então.

\section{2. “O SERTÃO VAI VIRÁ MAR”: Nova Iorque, cidade submersa na memória.}

Daqui a diante, sigo os rastros das memórias dos moradores. Os primeiros indícios nos levam às origens do nome da cidade: Nova Iorque. De acordo com os relatos, deve-se este nome ao engenheiro norte-americano Edward Burnet. No imaginário social da cidade, em meados do século XIX, o estrangeiro chegara àquelas paragens. Havia sido nomeado pelo Governo do Império Brasileiro, chefe da missão, responsável por fazer a limpeza do Rio Parnaíba, desobstruindo-o das pedras que punham em riscos a navegabilidade das embarcações. Com o fim da missão, o ianque decide-se por fazer morada, ali, fundando uma vila, à qual cognominou de Vila Nova. Neste ínterim mandou erguer a primeira casa de alvenaria e coberta com telha, para logo em seguida abrir uma casa de comércio. 
Por volta do ano 1890, a Vila fora desmembrada do município de Pastos Bons ${ }^{5}$. Foi então que o engenheiro norte-americano, não só colaborou no planejamento do espaço arquitetônico da cidade, como também sugeriu-lhe o nome de batismo ${ }^{6}$, em homenagem a sua terra natal. Às margens do Rio Parnaíba, à época, principal rota de ligação com o sertão, Nova Iorque tornou-se um ponto estratégico para o comércio, graças ao porto da cidade em que ancoravam-as grandes e pequenas embarcações ${ }^{7}$.

Todavia, por volta de ano de 1929, a cidade sofre sua primeira grande inundação. Devido às fortes chuvas que caíram, quando "choveu quatro dias, dia e noite sem parar", os habitantes da "velha Nova Iorque" foram apanhados de surpresa pelo transbordamento do rio Parnaíba. Em meio à tempestade a cidade fora invadida pelas águas e os moradores viveram, pela primeira vez, a tragédia de quem viu tudo escorrer rio abaixo. $\mathrm{Na}$ ocasião, todas as residências, prédios públicos e casas comerciais foram destruídas pelas forças das águas. Assim nos contou Dona Mariquinha Ferreira": "essa enchente é que foi grande, foi que acabou a cidade toda, toda, todinha. Choveu quatro dias, dia e noite sem parar". Após a tempestade, não veio à bonança. Era hora de enxugar as lágrimas e arregaçar as mangas. Naquele mesmo ano, paulatinamente, os moradores foram reconstruindo a cidade, desta vez em terreno mais alto do que o antes escolhido pelo o engenheiro ianque.

Conta ainda D. Mariquinha, que durante o trabalho de reconstrução da "Nova-Nova Iorque", os moradores não contaram com nenhum tipo de ajuda por parte do governo estadual ou mesmo federal. Diante da nova empreitada, os nova-iorquinos se esforçaram por erguer e manter a nova cidade "igualzinha àquela que escorreu rio abaixo, com suas treze ruas e duas praças [...] Todos ficaram morando na mesma rua que morava antes" (D. Mariquinha, 92 anos). Desse modo, o esforço para reconstruir a cidade vai além do projeto arquitetônico em mantê-la "igualzinha àquela que escorreu rio abaixo". Procurou-se, também, manter os mesmos valores morais, sociais e culturais, preconceitos, visão de

\footnotetext{
${ }^{5} \mathrm{Na}$ época, Vila Nova pertencia ao município de Pastos Bons, que durante a segunda metade do Século XVIII, segundo Cabral, foi ponto de apoio para o avanço do processo de ocupação e conquista do sul do Maranhão. Os campos naturais contínuos e exuberantes foram condicionantes para o avanço da frente de vaqueiros vindos da Bahia e Pernambuco, devido às condições indispensáveis para o desenvolvimento da pecuária extensiva e itinerante, conforme Cabral, Maria do Socorro Coelho: Caminhos do gado: conquista e ocupação do sul do Maranhão. São Luís: Sioge, 1992.

${ }^{6}$ Somente em 1938, Nova Iorque foi elevada à categoria de cidade pelo decreto-lei $\mathrm{n}^{\circ} 45$, em observância à lei Nacional $\mathrm{n}^{\mathrm{o}} 331$ do mesmo ano.

${ }^{7}$ Ressalta-se que até a década de 1960, o rio Parnaíba ainda era a principal rota de comercialização entre os estados do Piauí, Maranhão e Tocantins, na época, também chamada Norte do Goiás.

${ }^{8}$ Mariquinha Ferreira, 92 anos. Entrevista concedida ao autor em Nova Iorque, em 21/02/2005.
} 
mundo, hábitos, poder de mando, violência física e simbólica, dantes existente. Haja vista que:

Lá na cidade velha, era assim: era social né! Pessoa de muita cor dançava na Rua dos Pretos ou na União. Não era nem doido de pisar no Casino, porque se fosse era barrado na porta. Rapariga nem tinha o direito de olhar a festa social, de família. Fosse no Casino, fosse na União, não ia [...] A rua dos cabarés era uma só: Lá no Cai N'água. Porque era na beira do rio e qualquer rapapé que os homens faziam as mulheres pá n'água. Lá também tinha muito racismo! Negro lá não entrava na festa de branco e branco também não ia na festa de preto (D. Francisquinha, 80anos. Entrevista concedida ao autor em Nova Iorque, em 22/02/2005.)

Das imagens que fluem dos relatos de memória de D. Francisquinha, tem-se a visão de uma cidade com seus espaços socialmente esquadrinhados: "lá na cidade Velha era assim: era social né"?! O ser social nova-iorquino se fazia notar nos salões dos clubes de festas. Ou seja, são nas festas que as fronteiras se evidenciam, fazem-se socialmente intransponíveis. Numa cidade em que o espaço de convivência é demarcado pela exclusão social, em que a cor da pele se faz determinante, "pessoa de muita cor dançava na rua dos pretos”. Eram nos salões dos clubes que se constituíam os lugares de práticas recíprocas de exclusão social, dando maior visibilidade para as regras de convivência socialmente estabelecida, pois "lá também tinha muito racismo! Negro lá não entrava na festa de branco e branco também não ia à festa de preto". Noutras palavras, em Nova Iorque do Maranhão, "branco é branco, preto é preto e a mulata não é a tal" (VELOSO, 1992). Assim sendo, ao estabelecerem locais apropriados para reuniões e festas na cidade, o lugar não deixa de funcionar como um espaço de representação das classes sociais.

Todavia, para D. Francisquinha, pior do que ser mulata, pessoa de muita cor, negro, era a condição de "rapariga". A "mulher da vida", a "desregrada", "a doidivanas" era a figura que deveria ser socialmente "repudiada", "execrada", "excomungada", "apedrejada" e principalmente evitada, aviltada no convívio público, de acordo com os padrões morais da "boa família", sendo estas péssimas influências para as "moçoilas casadoiras": "rapariga nem tinham o direito de olhar a festa social, de família”. Neste sentido, cada espaço da cidade determina sua forma de funcionamento e segue as regras morais e simbolicamente estabelecidas que as "circunscrevem em um complexo campo de relações". Assim sendo, de acordo com Guimarães Neto, "os confrontos e práticas desviantes, consideradas como próprias dos bordéis, não se enquadram segundo as regras sociais dominantes nos núcleos das cidades, mas nem por isso, anulam-se ou são recusadas" (GUIMARÃES NETO, 2006, p.137). 
Percebe-se, ainda, que por intermédio dos relatos a delimitação do espaço físico e social da cidade em que as "raparigas" podiam freqüentar, assim como habitar. Ou seja, as "casas de cômodos", "morada das mulheres de vida fácil”, "antro de pecado", "o cabaré”, qualquer que seja sua denominação, situavam-se na zona periférica da cidade, sendo o lugar mais conhecido pela acunha: "rua dos cabarés". Em tom mais prosaico, a rua dos cabarés também era chamada de Beco do Cai n’água: "qualquer rapapé que os homens faziam, as mulheres, pá n’água”. Espaço de diversão, de prazer, os cabarés também aparecem como espaço propício à violência. Desse modo, para escapar dos prováveis espancamentos, surras, as "raparigas", quando ameaçadas por "qualquer rapapé" se atiravam nas águas do rio, fugindo dos possíveis agressores. O "Beco do Cai n`água” aparece como um espaço de contrastes, um espaço incrustado noutro espaço, coexistindo de maneira ora desejável, ora indesejável, de acordo com a produção de práticas socialmente engendradas, pois "delineiam-se assim, no fazer cotidiano dessas populações, linhas imaginárias, dividindo, desde já, mundos, tempos e regras. Nomeiam-se os lugares, mediante as práticas do espaço" (GUIMARÃES NETO, 2006, p. 138).

Os quadros sociais da cidade, pintados pelos relatos de memória de Dona Francisquinha, não refletem apenas os traços dos lugares, tempos e espaços, locais de convivências que cada indivíduo ou grupo podia freqüentar e ocupar, ao longo das redes de convivências tecidas em Nova Iorque. Demonstram, também, como esses espaços, tempos e lugares habitam nas memórias dos que contam as histórias da cidade. D`outra maneira, estes espaços estão arraigados nas memórias de "experiência vivida e em emoções profundamente sentidas" (PORTELLI, 2002, p.126). Ao recortarem a cidade em pedaços, as lembranças dos narradores não revelam apenas os lugares, tempos e espaços das memórias, mas servem como esteio para reconstrução simbólica do universo social da "velha cidade", amarrando os nós com as linhas das lembranças capazes de costurar tempo e espaço vivenciado/rememorado, tirando o véu da sua existência, tal como é proseada. Diz Guimarães Neto que:

\footnotetext{
Nas entrevistas se descobrem às imagens mais significativas do ponto de vista das pessoas que passaram pela experiência dos primeiros tempos, relacionadas a acontecimentos comuns e mesmo inusitados, que os relatos orais retransmitem ou (re)apresentam, para constituir um passado/presente da comunidade (GUIMARÃES NETO, 2005, p. 10).
}

Contudo, o episódio que marcou a última e definitiva destruição-reconstrução da cidade de Nova Iorque deu-se no início da década de setenta, deixando, assim, profundas 
marcas na história de vida dos moradores da cidade. O cenário nacional é fortemente marcado pela atuação dos militares no poder, ou seja: a truculência dentro do miraculoso plano de desenvolvimentismo do país. No rabo do cometa progressista, a cidade foi novamente tragada pelas águas do rio, em decorrência da construção da Barragem da Hidroelétrica da Boa Esperança, lançando os moradores em mais uma "grande tragédia" de suas vidas, causando-lhes duros sentimentos de perda, assim como deixando marcas indeléveis em suas memórias. Valendo-se dos meios de comunicação, os governantes faziam soar os ecos do discurso majestoso sobre a grandeza do país, do "milagre econômico", ancorado na idéia de modernização, que deveria integrar os Estados do Maranhão e Piauí ao modelo de desenvolvimento de outras regiões, notadamente o "Sul maravilha".

Os ventos da modernidade também sopravam por estas paragens. Revestidos com o verniz do novo, os ecos da modernidade faziam-se ouvir em praça pública e a "Boa Esperança" é anunciada pela voz em off, como uma "mensagem de progresso", quando do discurso de posse do então eleito Governador José Sarney, e assim captado pela lente cinematográfica do jovem cineasta e precursor do Cinema Novo, Glaúber Rocha: ${ }^{9}$

Temos os nossos olhos, nesta tarde, no começo do governo, voltados para aquela barragem de cimento que atravanca o Parnaíba e que nos acena como uma mensagem de progresso, e que se chama Boa Esperança [...] o Parnaíba é tomado para que o Maranhão e o Piauí possam transformar aquela zona na mais próspera do Norte/Nordeste, onde terá a garantia de um Estado descente (ROCHA, 1966).

Em seu discurso de posse, o eleito Governador do "Maranhão Novo", José Sarney, toma a barragem como algo que lhe "acena como uma mensagem de progresso". O novo governo tem os olhos voltados para "aquela barragem de cimento que atravanca o Parnaíba" como um símbolo capaz de "transformar aquela zona na mais próspera do Norte/Nordeste" arrancando os estados do Maranhão e Piauí dos seus mais tétricos quadros de miséria e onde se "terá a garantia de um estado descente".

Em sua verborragia de palanque, o recém eleito governador diz mais:

O Maranhão não quer a miséria, a fome, o analfabetismo, as mais altas taxas de mortalidade infantil, de tuberculose, de malária, de xistossoma, como exercício do cotidiano. O Maranhão não quer morrer sem gritar, não quis morrer estático de olhos parados e ficar caudatário marginal do progresso, olhando o Brasil e o Nordeste progredir, enquanto nossa terra mergulhava na podridão, não podia marchar, nem caminhar (ROCHA, 1966).

\footnotetext{
${ }^{9}$ Ao tomar posse do cargo de governador do Maranhão, José Sarney encomendou o curta-metragem ao jovem e premiado cineasta Gláuber Rocha: Maranhão 66: posse do governador José Sarney - Reportagem de Gláuber Rocha e Fernando Duarte. Curta metragem, 35mm, preto-e-branco, 10 .
} 
Por um lado, fazendo uso dos aparelhos midiáticos, os "mensageiros do progresso", alardeavam por intermédio de jornais, rádios, cinemas e televisão a construção da barragem da Boa Esperança, como um emblema do progresso, de modernização e desenvolvimento do Estado do Maranhão como podemos perceber na reportagem estampada nas páginas do Jornal O Imparcial:

O Dr. César Cals, presidente da Companhia Hidroelétrica de Boa Esperança (Cohebe), manterá contato hoje com a imprensa, rádio e televisão de São Luís. Aquele ilustre titular, na oportunidade, fará exibição de um filme documentário sobre a obra da barragem de Boa Esperança no cine Roxy. Estarão presentes, devidamente convidados, autoridades, as classes industriais, comercial e bancária, além de famílias de nossa sociedade. Trata-se de uma película de maior interesse para os Maranhenses (O IMPARCIAL 21/06/ 1969. p.06).

Enquanto isso, do outro lado do espelho, no reverso da vitrine, vozes que não fazem ecos. O que ressoa nos tímpanos dos moradores da "velha Nova Iorque" é dissonante em relação às imagens que lhes saltam aos olhos. Diante das vistas, os ecos ganham sons de sofrimento, de abandono, tragédia, destruição, desespero e desesperança de ver a cidade mais uma vez ser engolida pelas águas da Boa Esperança: "isso foi à maior tristeza do mundo" (Sr. CÍCERO, entrevistas concedida em 2006). Nesse sentido, rememorar para essas pessoas é viver, através da memória individual e coletiva, imagens, fatos, histórias, pessoas, que, de outra maneira, ficariam para sempre silenciadas no fundo do lago da Boa Esperança. Rio, cidade, tempos e espaços de convivências perderam-se das vistas para compor quadros sociais e da vida que só existem nas molduras das memórias dos narradores, pois "contar histórias sempre foi a arte de contá-las de novo, e ela se perde quando as histórias não são mais conservadas (BENJAMIM, 1994, p. 205).

Neste sentido, a nova-nova-Nova Iorque foi edificada de acordo com os moldes dos milhares de conjuntos habitacionais ${ }^{10}$, construídos pelo país afora, com suas casas iguais, suas fachadas indistintas, apagando todos os sinais de diferenciação e impulsionando os personagens a representarem seus papéis, suspensos no tempo e espaço, como podemos depreender no relato do Sr. Pedro:

Tinha neguinho que não acertava nem com a casa. Ele chagava e entrava na minha, entrava na casa do outro, todo perdido sabe? [...] Moço foi uma verdadeira calamidade! A gente não sabia o que fazia, a gente não sabia trabalhar, num sabia se movimentar em nada, a gente não sabia nem pra onde ia [...] A morte de Nova Iorque foi essa represa [...] Por quase quatro meses, todos os dias a gente ia pra praça e ficavam todos zanzando de um lado para o outro. Não tinha nada pra fazer, não sabia fazer nada, ficamos feito fantasmas fazendo assombração (Entrevista concedida ao autor em Nova Iorque, em 20/02/2005).

\footnotetext{
${ }^{10}$ A construção da Nova-Nova-Nova Iorque ficou a cargo da Companhia hidroelétrica da Boa Esperança (Cohebe), através de convênio com o Estado do Maranhão e o BNH.
} 
Enquanto os jornais, rádios, televisão, cinemas e governantes comemoravam a construção da barragem como uma "mensagem de progresso", para Sr. Pedro e moradores da "velha Nova Iorque" o aceno era de despedida, de adeus, "de uma verdadeira calamidade". O que flui dos relatos são as imagens dos moradores "perdidos" e confusos no novo espaço da cidade, pois "tinha neguinho que nem acertava com a casa". As transformações causadas nas vidas das pessoas provocam-lhes sentimentos de estranhamentos a ponto de não mais reconhecerem as próprias moradas. As imagens que fluem das lembranças do Sr. Pedro são das pessoas que ficaram "zanzando de um lado para outro", já que "não tinha nada para fazer, não sabia fazer nada, ficamos feito fantasmas fazendo assombração".

Nem tudo foi só lamento, calamidade. Os relatos de memórias se desvendam e remetem-nos aos embaralhamentos de fios de lembranças que se encontram no tempo e espaço onde se deu a inundação da cidade. Aqui se desvenda mais uma ponta do novelo da memória. Observando do ponto de vista dos "ganhos matérias", da qualidade de vida, podese dizer que a construção da nova cidade proporcionou significativas transformações para a maioria dos moradores. Refiro-me à grande maioria vivia na condição de agregados nas terras dos fazendeiros, habitando em casas de taipa coberta com palha e com mínimas condições de sobrevivência e sob "o medo do fogo" que, em minutos, transformavam suas "taperas" num amontoado de cinzas, onde "um dia é todo para esperança, o seguinte para desconsolação" (ROSA, 2006, p. 410). Neste sentido, receber uma casa de alvenaria representou para esses moradores um significativo avanço para melhor qualidade de vida, conforme nos relata D. Teresa:

\footnotetext{
"a melhora que eu tive foi que eu recebi essa casa. Agora eu posso sair tranquila sem medo de fogo. [...] Tinha uma casinha de paia na Rua do Coquinho. Era de paia em riba e em baixo, tapada. Quando era anoitinha, eu criava sete gato, só assuntava era os gato mexeno, matano cobra" [...] Agora, que eu acho que lá na cidade véia era mais mió, isso era [...] há não ser por essa casa, eu merma tenho muita sordade da outra cidade." (D. Teresa, 64 anos. Entrevista concedida ao autor em Nova Iorque, em 04/04/2008.)
}

Como se pode observar, embora tenha ganhado uma casa de alvenaria, podendo sair "sem medo de fogo" destruir o pouco que lhe pertencia, para Dona Tereza, a vida na "cidade véia era mais mió". Desse modo, a melhor qualidade de vida proporcionada pela aquisição de bens matérias, uma casa de alvenaria, não são suficientes para apagar das lembranças os sentimentos e a "sordade da outra cidade". Ou seja, ao construírem imagens da cidade pelas narrativas das memórias, partindo de pontos de vista diferentes, o lugar social que os 
narradores ocupam ou ocuparam nas histórias que narram, as lembranças rememoradas acabam convergindo para pontos comuns, nos permitindo pensar o universo investigado como parte de uma geração que vivenciou situações sociais próprias e que não se deixa confundir com a geração atual.

\section{TEMPOS, ESPAÇOS E LEMBRANÇAS DE MEMÓRIAS TRAUMÁTICAS.}

Chega-se à cidade de Nova Iorque por uma larga avenida de mão dupla que avança e circula uma grande praça planejada e abandonada. Pelas ruas, poucos são os transeuntes. Tem-se a sensação de haver chegado a um lugar parado no tempo. A escolha da cidade não se deu ao acaso, mas por acreditar que ali habitam pessoas que vivenciaram experiências próprias, traumatizantes, não planejadas, indesejadas e imprevisíveis em suas histórias de vidas. Não tardou para eu perceber que ali, embora pareça, o tempo não havia parado, mas que havia uma multiplicidade de tempos, tempos justapostos. Percebo logo que o tempo marcado pelo calendário, o tempo registrado pelo relógio, linear e cronológico, se faz desnecessário em sua homogeneidade e seu vazio. A multiplicidade de tempos se faz notar por uma cadeia de elementos constitutivos que fragmentam e unificam o tempo simultaneamente. Tanto é que os moradores criaram suas próprias categorias temporais para se referirem à "cidade velha" após ficar submersa pelas águas represadas pela barragem: "no tempo das balsas", "no tempo dos coronéis", "no tempo da cidade velha", "no tempo dos revoltosos". Tempo e espaço entrecruzam-se de tal forma que:

\footnotetext{
Por vezes acreditamos conhecer-nos no tempo, ao passo que se conhece apenas uma série de fixações nos espaços da estabilidade do ser, de um ser que não quer passar no tempo; que no próprio passado, quando sai em busca do tempo perdido, quer 'suspender' o vôo do tempo. Em seus mil alvéolos, o espaço retém o tempo comprimido (BACHELLARD, 1998, p.28).
}

Assim é Nova Iorque, uma cidade de "tempo comprimido" no espaço labiríntico da memória, pois "nesse teatro do passado que é a memória, o cenário mantém os personagens em seu papel dominante" (BACHELLARD, 1998, p. 28). Ou seja, mais que no tempo, é no e pelo espaço que pudemos encontrar "os belos fósseis de duração concretizados por longas permanências" (BACHELLARD, 1998, p. 29). Muito mais que no tempo, é através do espaço da cidade velha que a lembrança dos entrevistados ativa a memória de outrora. É por intermédio das lembranças dos espaços de convivência da velha Nova Iorque que os narradores percebem as transformações ocorridas no tempo: 
Na cidade velha tudo isso tinha, tudo isso lá tinha, tinha clube muito decente, lá tinha União Artística muito decente, tinha tudo quanto era sócio, lá tinha uma casa onde os morenos faziam suas festas. Aqui nada disso tem! Tem um clube bem ali na ponta da rua, chamam de clube. Faz até vergonha você dar suas passadas para ir olhar uma coisa daquela, só essa molecada bêbada dizendo palavrão e querendo brigar sem ter coragem (Sr. PEDRO. Entrevista concedida ao autor em Nova Iorque, em 20/02/2005).

Em seu relato, ao realizar essa projeção do passado no presente, o Sr. Pedro está identificando as marcas de uma continuidade pouco notável, assim como revelando a memória como lugar de persistência, de continuidade, de capacidade de viver o hoje inexistente. Percorrendo as trilhas das lembranças e dos espaços de realizações das festas na/da cidade velha, Sr. Pedro olha para trás para evidenciar valores morais e modos de vida de outrora que se perderam e contrastam com o viver na Nova Iorque de hoje, já que "faz até vergonha você dar suas passadas para ir olhar uma coisa daquela”. Rememora os espaços diferenciados onde se realizavam as festas conforme cada grupo social, mas que diferentemente da cidade de hoje tudo era muito decente, pois "na cidade velha [...] tinha um clube muito decente (Casino), lá tinha União Artística muito decente, tinha tudo quanto era sócio, lá tinha uma casa onde os morenos faziam suas festas”. Diz Sr. Pedro que na Nova Iorque de hoje só restou "essa molecada bêbada dizendo palavrão e querendo brigar sem ter coragem". Ao trazer para o presente esses espaços de sociabilidades, o narrador cria o que Pierre Nora chamou de "lugares da memória". Para este autor os lugares da memória são vistos como resquícios de um tempo pretérito que é desejado como forma de reconstituição das identidades, laços com a tradição. Lugares que aparecem como artifícios para proteger o passado diante de um presente que dilui as tradições e assola a memória espontânea. Neste sentido, para Nora os Lugares são:

\footnotetext{
Antes de tudo restos, já que os lugares de memória nascem e vivem do sentimento [...] São bastiões em que nos escoramos, pois se aquilo que eles defendem não estivesse sob ameaça, não seria também preciso reconstruí-los. Se vivêssemos verdadeiramente as lembranças que encerram, eles seriam inúteis [...]. É esse vai-e-vem que os constitui: momentos de história extraídos ao movimento da história, mas que lhe são devolvidos (NORA, apud PIMENTEL, 1998, p. 299-300).
}

Desse modo, a inundação de Nova Iorque significou para os moradores a "morte da cidade", etapa fundamental na luta cotidiana pela sobrevivência social, psicológica e cultural. O termo "morte da cidade" é muito recorrente na memória dos narradores e é usado aqui pelo Sr. Pedro como sinônimo da construção da barragem da Boa Esperança: "Agora a morte de Nova Iorque foi essa represa". O termo "morte de Nova Iorque" é constantemente (re) elaborado pelos moradores por intermédio de outras significações, podendo ser interpretada como uma categoria local, servindo assim para aqueles que utilizam se situarem 
no tempo e no espaço, pois "a morte é a sanção de tudo o que o narrador pode contar. É da morte que ele deriva sua autoridade" (BENJAMIM, 1994, p.208).

Contudo, as memórias da Cidade de Nova Iorque, contidas neste conjunto de narrativas orais, aparecem associadas a outras, intimamente relacionadas com certos aspectos das histórias coletivas e individuais da vida de cada um, pois "nossas lembranças permanecem coletivas e nos são lembradas por outros, ainda que se trate de eventos em que somente nós estivemos envolvidos e objetos que somente nós vimos" (HALBWACHS, 2006, p.30). Ou seja, como a cidade já havia passado pelo processo de destruição causada pela enchente do Rio, suas memórias se inscrevem num contexto mais amplo pela sobrevivência individual e coletiva. Dito de outra maneira, seus relatos nos remetem aos entrelaçamentos, às filigranas de memórias que se encontram no tempo e no espaço onde aconteceram às inundações.

Vivendo à margem dos debates e conflitos políticos que marcaram esse período, no país, e, por extensão, o Estado do Maranhão, à época da construção da barragem, era-lhes difícil entender, por exemplo, as idéias de progresso anunciadas nas páginas da imprensa e pelos alto-falantes-oficiais, conforme este trecho da reportagem do jornal $O$ imparcial, quando da inauguração da Boa Esperança: "para os estados do Piauí e Maranhão, a inauguração da Boa Esperança está sendo denominada de festa do século" (O IMPARCIAL, 1970, P. 3). Bem como, por outro lado, foi difícil, também, para os moradores de Nova Iorque, entenderem e aceitarem o fato de que a cidade desapareceria das vistas, seria dragada pelas águas da barragem:

Eles prometeram mundos e fundos, que era um céu aberto, não sei o quê, isso e aquilo. Moço, foi uma verdadeira lástima que não deu em nada! [...] Quando eles saíram daqui, a Companhia, pronto, acabou tudo! Aí ficou tudo debaixo d’água, a cidade morta, esta aqui, porque acabou o trânsito marítimo ( $\mathrm{Sr}$. PEDRO. Entrevista concedida ao autor em Nova Iorque, 20/02/2005)

Seguindo as trilhas dos relatos de memória do Sr. Pedro, durante o processo de construção da barragem, foram-lhes prometido, pelos governos, "mundos e fundos", no entanto, em sua interpretação, a "Nova-Nova-Nova Iorque" construída pelos novos "mensageiros do progresso" não ia além da imagem de uma "cidade morta". Com a saída da Companhia, "acabou tudo", o sertão virou mar e "tudo ficou debaixo d’água". Contudo, o golpe de misericórdia foi o fim do trânsito marítimo: "cidade morta, esta aqui, porque acabou o trânsito marítimo". Percebe-se, ainda, que a imagem de uma "cidade morta" não reflete às sombras da "velha cidade", que ficou submersa pelas águas, mas sim, os vultos da "cidade nova", à época, recém entregue aos moradores. Nas imagens que saltam dos relatos 
de memórias do Sr. Pedro, o Parnaíba é visto também como um defunto sepultado nas águas escuras da Boa Esperança, pois perdera sua importância, seu significado, seu movimento,

Foi-se acabando. O próprio Parnaíba perdeu aquele entusiasmo que ele tinha. Ele era entusiasmado e nós tudo compactuava com ele, achava ele lindo. Eu ficava sentado lá na minha porta, na hora dessas (era final de tarde), vendo as balsas que descia e os vapores que chegavam, eu enxergava tudo (Entrevista concedida ao autor em Nova Iorque, em 20/02/2005)

Como se percebe, no relato, com a construção da barragem, o rio também foi perdendo seu entusiasmo, foi "se acabando". Nas correntezas que passam pelas lembranças da representação coletiva, os moradores tinham um pacto com o rio e admiração pelo rio: "nós tudo compactuava com ele, achava ele lindo". Por outro lado, nos quadros particularizantes da memória individual tem-se a imagem do homem, que no final de tarde, ficava sentado na soleira da porta, observando o vai-e-vem das balsas que desciam e dos vapores que subiam: "eu ficava sentado lá na minha porta, $[\ldots]$ vendo as balsas que descia e os vapores que chegava, eu enxergava tudo". Sendo assim, o rio Parnaíba foi perdendo seu entusiasmo, promovido pelo constante vai-e-vem de balsas e vapores que deslizavam pelas fortes correntezas de suas águas, e que aos poucos foi cedendo espaço, "foi se acabando" na calmaria das águas represadas da Boa Esperança, uma "verdadeira lástima que não deu em nada”, segundo Sr. Pedro.

A maneira como os moradores de Nova Iorque narram suas lembranças do tempo das inundações nos permite aproximá-los da análise feito por Walter Benjamim, em $O$ Narrador, pois "a experiência que passa de pessoa a pessoa é a fonte a que recorreram todos narradores. E entre as narrativas escritas, as melhores são as que menos se distinguem das histórias orais contadas pelos inúmeros narradores anônimos" (BENJAMIM, 1994, p. 205). Ainda de acordo com Benjamim, o narrador mantém suas características no povo; é um homem simples que geralmente se dedica a trabalhos artesanais; tem sempre uma moral da história entranhada em sua narrativa; ou seja, o narrador é aquele que imbrica sua experiência narrada com a própria vida, pois "assim se imprime na narrativa a marca do narrador, como a mão do oleiro na argila do vaso" (BENJAMIM, 1994, p. 205). A partir da tipologia dos narradores, benjaminiano (o viajante e o camponês sedentário), os moradores de Nova Iorque afeiçoam-se com o segundo tipo, já que são pessoas que não abandonaram o lugar onde nasceram e, como lembra ainda Benjamim, "também escutamos com prazer o homem que ganhou honestamente sua vida [...] e que conhece suas histórias e tradições" (BENJAMIM, 1994, p.198). 
Como estavam envolvidos direta e indiretamente no processo de construção da hidroelétrica, aos poucos os moradores foram construindo suas visões de mundo, suas interpretações, de acordo com suas experiências traumáticas, assimilando-a como batalha cotidiana pela sobrevivência física e simbólica, de tal forma, que podemos ver que tais "seus "vestígios estão presentes de muitas maneiras nas coisas narradas, seja na qualidade de quem as viveu, seja na qualidade de quem as relata" (BENJAMIM, 1994, p.205).

Noutro relato exemplar, o Sr. Benedito nos descreve, com muita força, as experiências dolorosas vividas por ele e pelos demais moradores, ao ver sua cidade onírica deixar de ser espaço de aconchego, de proteção, de reconhecimento de si e dos seus, ser engolida pela fúria avassaladora das águas do Parnaíba que, d’ora em diante seria as águas, ironicamente, para eles, chamadas de Boa Esperança: "ficamos o seguinte: muita gente chorava, muita gente não queria aceitar. A situação foi tão precária que até os bichos sofreram. No começo, era todo mundo triste, preocupado, achando que não dava para viver aquelas coisas". Verifica-se o quão difícil foi para os moradores aceitarem a destruição da "Cidade Velha", assim como foi sofrido e doloroso o processo de adaptação na Nova-NovaNova Iorque, pois a situação ficou tão precária que "até os bichos sofreram". Assim, o reinício da vida na "cidade nova" foi marcado por momentos de incertezas, preocupações, tristezas, recusas, pois “muita gente chorava, muita gente não queria aceitar". Não somente foram transplantados no espaço, mas, principalmente, em suas rotinas, hábitos, costumes, de tal forma que os moradores já não conseguiam mais reconhecer a cidade como sua, mas trazendo-lhes, não só estranhamento, como insegurança, já que "no começo era todo mundo triste, preocupado, achando que não dava para viver aquelas coisas”.

\section{CONSIDERAÇÕES FINAIS}

Escolhi Nova Iorque-Ma como ponto de observação e de análise, neste sentido, com o propósito de entender como os moradores tecem suas narrativas, tendo como referência os fatores tempo e espaço; como elaboram suas representações, através da memória, no entorno dos momentos de destruição/reconstrução da cidade e de suas vidas.

Nesta perspectiva, a escolha de mulheres e de homens em idade avançada, aqueles que nos confiaram uma nesga de suas memórias, não foi por acaso, mas por entender que suas lembranças alcançam um passado mais distante e porque o tempo que dispõem para narrar suas experiências é mais elástico, porque menos atravessado de obrigações cotidianas. 
Outro motivo é que as narrativas, as histórias de vida individuais e coletivas "ouvidas" durante a pesquisa de campo, apontam para aspectos da vida dos moradores o que nos permite interpretar as mudanças físicas, simbólicas e culturais das cidades, mediante a fato de estas trazerem à superfície um conjunto de representações, ressemantizações, referentes ao processo de transformação das vivências trágicas de suas vidas, provocadas pelas enchentes do Rio Parnaíba.

Noutras palavras, a oralidade dá margem a que interpretemos os diversos significados que indivíduos e grupos sociais conferem aos testemunhos das experiências vividas. Assim sendo, enfatiza que a construção dos relatos das histórias contadas pelos moradores de Nova Iorque, serve, enquanto instrumento de reação contra a dissolução de toda uma teia de relações outrora estabelecida em nas malhas de sentidos e significados, esforços resignados de homens e mulheres que se recusam em aceitar as marcas do presente perpétuo, da pura, simples, legítima, humana e cruel decadência.

\section{REFERÊNCIA BIBLIOGRÁFICA.}

BACHELARD, Gaston. A poética do Espaço. São Paulo. Martins Fontes, 1998.

BENJAMIM, Walter. Magia, técnica, arte e política. São Paulo: Brasiliense, 1994. (Obras escolhidas; v.1)

CABRAL, Maria do Socorro Coelho. Caminhos do gado: conquista e ocupação do sul do Maranhão. São Luís, Sioge, 1992.

GEERTZ, Clifford. A interpretação das culturas. Rio de Janeiro, LTC, 1989.

DELEUZE, Gilles. Proust e os signos. Rio de Janeiro: Forense Universitária, 2006.

GUIMARÃES NETO, Regina Beatriz. "Personagens e memórias. Territórios de ocupação recente na Amazônia". In: CHALHOUB, Sidney, NEVES, Margarida de Sousa, PEREIRA, Leonardo Affonso de Miranda. História em cousas miúdas. Capitulo de história social da crônica no Brasil. Campinas, Ed. da Unicamp, 2005.

Cidades da mineração: memórias e práticas culturais: Mato Grosso na primeira metade do século XX. Cuiabá. EdUFMT, 2006.

HALBWACHS, Maurice. A Memória Coletiva. São Paulo: Centauro, 2006.

LOPES, Raimundo. Uma região tropical. Rio de Janeiro. Cia. Editora Fon-Fon e Seleta, 1970. 
POLLAK, Michael. Memória, esquecimento, silêncio. In. Estudos Históricos. Rio de Janeiro: CPDOC/FGV, vol. 2, n. 3, 1989, p.3-15.

Memória e identidade social. In. Estudos Históricos. Rio de Janeiro: CPDOC/FGV, vol. 5, n. 10, 1992, p. 200-212.

PORTELLI, Alessandro. "O massacre de Civitella Val di Chiana (Toscana: 29 de junho de 1944): mito, política, luto e senso comum”. In: AMADO, Janaina \& FERREIRA, Marieta de Moraes (orgs). Usos e Abusos da História Oral - 5ª Ed. - Rio de Janeiro: Ed. FGV, 2002.

ROCHA, Glauber. Maranhão 66: posse do governador José Sarney. Curta metragem, 35 $\mathrm{mm}$, preto-e-branco.

RICOEUR, Paul. O conflito das interpretações: ensaios de hermenêutica. Rio de Janeiro: Imago, 1978.

ROUSSO, Henry. "A memória não é mais o que era". In: AMADO, Janaina \& FERREIRA, Marieta de Moraes (orgs). Usos e Abusos da História Oral - $5^{\mathrm{a}}$ Ed. - Rio de Janeiro: Ed. FGV, 2002.

VELOSO. Caetano. Circuladô ao vivo. Philips, 1991. 